\title{
Evaluation of demands of inclusion, exclusion and alteration of technologies in the Brazilian Health System submitted to the National Committee on Technology Incorporation
}

\author{
Luciana Macatrão Nogueira Nunes ${ }^{1,2 *}$, Marta Maria de França Fonteles ${ }^{1,2}$, \\ Ana Cláudia Brito Passos ${ }^{1}$, Paulo Sérgio Dourado Arrais ${ }^{1,2}$
}

\author{
${ }^{1}$ Faculty of Pharmacy, Dentistry and Nursing, Pharmacy Department, Federal University of Ceará, Brazil, ${ }^{2}$ Post-graduation \\ Program in Pharmaceutical Sciences, Federal University of Ceará, Brazil
}

\begin{abstract}
The steady increase in the number of health technologies and advances in associated research generate management challenges in the choice of technologies to be made available to the public. From 2011, the process of inclusion, exclusion and alteration of technologies to the Brazilian Unified Health System (SUS) has undergone major transformations, such as the creation of the National Committee on Technology Incorporation (CONITEC). This study analyzed the decisions of CONITEC since its inception until July 2015. The analyzed variables were: type of technology, reason for application, name of the technology, indication, claimant and CONITEC decision status. We found that the Government was the main claimant, accounting for $58.1 \%$ of the 420 cases. The most frequent request was inclusion (93.8\%) and the technology type was medicine (61.4\%). Of the incorporated medicines, the classes of antineoplastic/immunomodulatory were the most frequent (39.47\%). Society's desire for inclusion of an increasing amount of health technology contrasts with the limited resources available to management, which causes budget concerns. Using Health Technology Assessment (HTA), advances resulting from these innovations in the process were highlighted, and challenges were identified for the management and the academic community.
\end{abstract}

Uniterms: Brazilian Unified Health System/evaluation. Brazilian Unified Health System/technology. Health Technology Assessment. Health Technology. National Committee on Technology Incorporation/ Brazil.

\section{INTRODUCTION}

The steady increase in the number of health technologies available on the market and the advances in research have created management challenges regarding the choice of technologies to be made available to the population (Banta, Almeida, 2009). Health Technology Assessment (HTA) is a multidisciplinary field of public policy study that seeks to synthesize knowledge regarding clinical, social, ethical, environmental and economical implications of health technologies. A major goal of HTA is to guide decision-making by managers responsible for health policies, especially in regard to incorporating,

*Correspondence: L. M. N. Nunes.Faculdade de Farmácia, Odontologia e Enfermagem. Universidade Federal do Ceará. Rua Alexandre Baraúna, 949, Rodolfo Teófilo - Fortaleza, CE. E-mail: lucianamacatrao2@yahoo.com.br excluding and modifying technologies available in a health system (Eddy, 2009).

Brazil has made official lists of the medicines to be provided by its public health system since 1964 . These lists were initially updated by a public agency called "Drugs Central Office" (CEME) and, since 1975, they have been called the National List of Essential Medicines (RENAME), which currently is in its 9th modern edition, of 2014, encompassing 840 items (Brasil, 2007). At first, this policy was more significantly related to Pharmaceutical Care, making little use of HTA knowledge. Requests for amendments of RENAME were referred to CEME, that took decisions guided only by general guidelines of the Ministry of Health and by standardized methodologies for drug analysis. There was not a defined frequency nor even a time frame for the list to be reviewed (Brasil, 2007).

The first steps towards institutionalizing the process though wich technologies are incorporated by 
federal health management only took place in 2006, with the creation of the Commission for Incorporation of Technologies (CITEC), a public agency of the Brazillian Ministry of Health (MH). In 2008, CITEC joined the Secretariat of Science, Technology and Strategic Inputs (SCTIE) (Novaes, Elias, 2013).

From 2006 to 2011, CITEC received 351 proposals for incorporation, exclusion or alteration of health technologies, incorporating 85 technologies, not incorporating 65, excluding eight, not excluding two, filing four requests, extinguishing seven for being outside its scope and, also, preparing and reviewing 95 clinical protocols and therapeutic guidelines (Silva, Petramale, Elias, 2012).

With the increasing pressure on managers of Brazil's public Unified Health System (SUS) to incorporate new technologies through actions of representatives of the pharmaceutical industry, patients, prescribers, medical companies, carriers and disease associations, as well as through judicialization of health issues, there was an escalation on the discussion of how to balance the guarantee of access to technology - as a step towards accomplishing the goal of universal health coverage - with its rational use and, also, with the sustainability of the system in the face of increasingly high costs (Capucho et al., 2012). The debate culminated when a public hearing was held by the Supreme Court in 2009, from which came several contributions accepted by the government, resulting in legislative changes in 2011 (Brasil, 2008; DECIT, 2011).

The new laws and regulations turned the processes of evaluation and incorporation of technologies to SUS into a state policy (Brasil, 2011a); replaced CITEC by the newly created SUS' National Technology Incorporation Comission (CONITEC); and changed the management model on the coverage of technologies by SUS, establishing the need to start an administrative proceeding to each demand of inclusion, exclusion and modification of health technology to the system (Brasil, 1999; Brasil, 2011a). CONITEC was given the responsability to conduct those proceedings based on scientific evidence, especially of HTA, on legal principles and on public management standarts. The result of the proceedings may reflect in the amendment of SUS' lists: the National List of Actions and Health Services (RENASES) and the RENAME. This, in turn, may modify SUS' coverage and consequently the effective delivery of actions, services, medications and procedures available for the population's health care. Therefore, the changes affect directly not only the users and the managers of SUS, but also all the pharmaceutical and healthcare industry in general.
Understanding that these institutional and legislative innovations set a new framework of HTA in Brazil, with repercussions, since 2012, on the course and result of the process of incorporation, exclusion and modification of technologies made available by Brazilian public health system and hence their availability to the assisted population, this study aimed to analyze the demands submitted to CONITEC, during a period of three years since its creation, and to examine the possible improvements of this new framework over previous models adopted by the country.

\section{MATERIAL AND METHODS}

This is a descriptive study, with a quantitative approach of the demands submitted to CONITEC for inclusion, exclusion and alteration of technologies to SUS, based on official data from the Brazilian Ministry of Health, from January 2012 to July 2015.

The data was collected through document analysis, by research from secondary sources, more specifically in the databases available for consultation from the MH's websites, namely: 1) application forms of the inclusion, exclusion and alteration technologies to SUS; 2) classification and categorization reports of the demands submitted to CONITEC; 3 ) individualized reports containing the foundations, decisions and recommendations regarding the demands evaluated by the CONITEC; 4) contributions and public consultations forms, relating to demands for the inclusion, exclusion and alteration technologies to SUS and, 5) ordinances of the Secretariat of Science, Technology and Strategic Inputs of the Ministry of Health (SCTIE/MH), with the publication of the decisions in these processes.

For this study, the collected information in the databases of the Ministry of Health were as follows: a) type of technology (medicines, procedures, products and protocols); b) type of request (inclusion, exclusion, expansion of use, preparation and review); c) name of the technology; d) indication; e) claimant (public entities, pharmaceutical and private entities linked to organized civil society) and; f) CONITEC decision status (regarding the inclusion, exclusion and alterations of technologies at SUS).

Regarding the status of the application, the processes that had a CONITEC decision on the merits of the application were considered 'complete', as well as those that were closed by formal issues (status of "demand already incorporated into SUS", "proposal rejected for not being in formal compliance with documentation", "processes closed at the request of the claimants, and 
"demands outside CONITEC scope"). The completed ones that did not meet the cases closed by formal issues were also classified according to the criteria of the Ministry of Health, "included", "not included" and "exclusion". On the other hand, demands considered unfinished, fell under the following status according to the MH: "under review", "documentation under compliance analysis", "under review after public consultation", "pending final assessment for publication" and "in the public consultation phase".

Among the types of technology, specific variables for medicines were established, compiling information regarding the indication of the incorporated medicines and the reasons for deciding not to include them. The incorporated medicines were classified according to the first and fifth ATC (Anatomical Therapeutic Chemical) levels.

We also collected information on the publishing of public consultations performed during the study period, observing the number of demands in progress and the number of completed consultations, with and without the contribution of society in general.

The collected data were stored and analyzed using Microsoft Office Excel 2013. The results were expressed as absolute and relative frequencies. Some variables were stratified by the type of claimant.

The research was authorized and approved by the Ethics and Research Committee of Ana Nery's Nursing School (CAAE: 07972412.3.0000.5238).

\section{RESULTS}

During the study period, 420 proposals were sent to CONITEC, with $394(93.8 \%)$ related to the inclusion, $21(5.0 \%)$ were exclusion requests, and five (1.2\%), were related to alteration requests (three for the expansion of technologies use and two for the review of Clinical Protocols and Therapeutic Guidelines-PCDT).

Public entities were the largest request claimants (58.1\%), followed by companies and laboratories $(35.7 \%)$, and private non-profit associations $(6.2 \%)$
(Table I). Among the requests submitted by public entities, only $2.4 \%$ (10 requests) were provocations by judicial authorities, with the rest $(55,7 \%)$ coming from the public authorities within the Ministry of Health structure, the Union, the States or the Cities. Medicines were the type of technology that resulted in the greatest number of requests among claimants (61.4\%).

Of the 420 requests submitted to CONITEC, $85.5 \%$ were classified as completed and $14.5 \%$ were still in some stage of the review process by CONITEC. In turn, of the 359 already completed, 137 (38.2\%) were accepted for inclusion of technology, 72 (20.1\%) were not incorporated and 18 cases $(5.0 \%)$ were for the exclusion of RENASES and RENAME technology. Seventy-two $(20.1 \%)$ cases were rejected due to problems with the documentation. In one case, the extinction occurred because the demand had already been incorporated into SUS before the application, while in $52(14.5 \%)$ cases, the proceeding was terminated at the request of the applicants themselves before the evaluation.

Table II shows the relationship between the claimants and the status of the decision or step the assessment of CONITEC was in, by type of technology. Regarding demands related to the government and which relate to medicines $(n=133), 39.1 \%$ of applications were incorporated and $11.3 \%$ were not incorporated. Regarding the Pharmaceutical Industry ( $\mathrm{n}=109), 16.5 \%$ of applications were incorporated, $40.4 \%$ were not incorporated, and $30.3 \%$ were refused for non-compliance of formal documentation; regarding the case of private non-profit associations $(n=16), 37.6 \%$ of applications were incorporated and $50 \%$ had the proposal rejected by non- compliance of formal documentation.

Regarding forwarded procedures related to the government $(n=83), 61.4 \%$ of applications were incorporated. In the case of private associations $(n=6)$, $83.3 \%$ were refused for non-compliance to formal documentation and $16.7 \%$ are in some stage of analysis. The Pharmaceutical Industry $(n=7)$ had $57,1 \%$ of its procedure's applications refused for the same

TABLE I - Types of technology distribution according to the claimant qualifications. January 2012 - July 2015, Brazil

\begin{tabular}{ccccc}
\hline $\begin{array}{c}\text { Claimant/Types of } \\
\text { technology }\end{array}$ & Government n (\%) & $\begin{array}{c}\text { Pharmaceutical } \\
\text { Industry } \mathbf{n}(\%)\end{array}$ & $\begin{array}{c}\text { Private Association } \\
\mathbf{n}(\mathbf{\%})\end{array}$ & TOTAL n (\%) \\
\hline Medicine & $133(54.5)$ & $109(72.7)$ & $16(61.5)$ & $258(61,4)$ \\
Procedure & $83(34)$ & $7(4.7)$ & $6(23.1)$ & $96(22,8)$ \\
Product & $26(10.7)$ & $32(21.3)$ & $4(15.4)$ & $62(14,8)$ \\
Protocol & $2(0.8)$ & $2(1.3)$ & - & $4(0,9)$ \\
\hline TOTAL & $244(58.1)$ & $150(35.7)$ & $26(6.2)$ & $420(100)$ \\
\hline
\end{tabular}


TABLE II - Request claimant distribution and status of the National Committee on Technology Incorporation (CONITEC), according to types of technology. January 2012 - July 2015, Brazil

\begin{tabular}{|c|c|c|c|c|c|c|c|c|c|c|c|c|}
\hline \multirow{2}{*}{$\begin{array}{l}\text { Claimants/CONITEC } \\
\text { decision status }\end{array}$} & \multicolumn{4}{|c|}{ Government n (\%) } & \multicolumn{4}{|c|}{ Pharmaceutical Industry n (\%) } & \multicolumn{4}{|c|}{ Private Associations n (\%) } \\
\hline & $\mathbf{M}$ & PC & PD & PT & $\mathbf{M}$ & PC & PD & PT & $\mathbf{M}$ & PC & PD & PT \\
\hline Incorporated & $52(39.1)$ & $51(61.4)$ & $9(34.6)$ & - & $18(16.5)$ & - & - & - & $6(37.6)$ & - & $1(25)$ & - \\
\hline Excluded & $16(12.1)$ & $2(2.4)$ & - & - & - & - & - & - & - & - & - & - \\
\hline Under analysis* & $12(9.0)$ & $2(2.4)$ & $7(27.0)$ & - & $8(7.3)$ & $1(14.3)$ & $2(6.2)$ & - & $1(6.2)$ & $1(16.7)$ & - & - \\
\hline $\begin{array}{l}\text { Closed according to } \\
\text { claimant's request }\end{array}$ & $28(21.0)$ & $6(7.2)$ & $7(4.2)$ & $2(100)$ & $5(4.6)$ & $1(14.3)$ & - & $2(100)$ & $1(6.2)$ & - & - & - \\
\hline Others*** & $10(7.5)$ & $17(20.6)$ & $1(8.3)$ & - & $1(0.9)$ & $1(14.3)$ & $4(12.5)$ & - & - & - & $1(25)$ & - \\
\hline TOTAL & 133 & 83 & 26 & 2 & 109 & 7 & 32 & 2 & 16 & 6 & 4 & - \\
\hline
\end{tabular}

$\mathrm{M}=$ Medicine; $\mathrm{PC}=$ Procedure; $\mathrm{PD}=$ Product; $\mathrm{PT}=$ Protocol. * under analysis; under review for compliance analysis; under review after public consultation. ** proposal refused for non-conformity of formal documentation. *** demand already incorporated into SUS; demand outside the CONITEC scope; pending final assessment for publication; in the public consultation phase.

reason of non-compliance to formal documentation. Regarding products, of the applications sent by the government $(\mathrm{n}=26), 34.6 \%$ were incorporated. As for the pharmaceutical industry, $59.4 \%$ had proposals rejected by non-compliance to formal documentation. The applications of private associations $(n=4)$ had only one request incorporated and another refused. Requests sent by the government and the pharmaceutical industry that involved protocols were all dismissed according to the claimant's own request.

Table III shows a list of incorporated medicines and their indications to the RENAME list. Of the 258 incorporation demands, submitted to CONITEC, 76 were approved, resulting in the incorporation of 50 different medicines and seven immunization products, being all organized under the first and fifth level of the ATC classification. Of the approved requests, 39.5\% were for antineoplastic/immunomodulatory medicines and $28.9 \%$ were for anti-infective for systemic use.

Table IV shows the reasons of CONITEC for the non-incorporation of 59 medicines to SUS. Each medicine application could be rejected for more than one reason, adding up to 120 reasons used in the non-incorporation decisions. In $25 \%$ of applications, the medicine was not included due to the fact the studies presented limited results of efficacy and/or safety of the medicine in question or failed to establish clinical benefit. In $18.3 \%$, the economic analysis was considered limited and the budget impact analysis seemed underestimated with estimates uncertainties generated by cost-effective analysis.

As for the results of civil society participation with the public appointments made by the CONITEC,
120 public consultations were performed using forms published by the MH in the Union's Official Gazette. Of this total, four were still current, while 116 were already concluded. Of the total of completed consultations, 106 received contributions from society.

\section{DISCUSSION}

Our findings show the extent of the process of inclusion, exclusion and alteration of technologies to SUS. CONITEC had a high demand for incorporation of new technologies, especially medicines. These demands come mainly from the public sector, which was the only sector that submitted requests to exclude repeated and inefficient technologies and to expand the use of medicines already incorporated. The Commission decided in $38.2 \%$ of inclusion requests in favor of the incorporation of the technology into SUS. Another important result concerns the significant participation of civil society in public consultations.

Evaluating the variable of the claimants of the process, we found the importance and the volume of public entities participating in this process, since the RENASES and the RENAME compositions directly influence the public health administration, not only at a federal level, but also state- and city-wise. Among the claimants classified as public entities, the Public Prosecutor's Office and the Ministry of Justice accounted for only ten demands in CONITEC.

The small number of cases initiated at the instigation of these judicial entities does not conclusively demonstrate the absence of interference or reduce the problem of judicialization of the SUS' technology inclusion process, 
TABLE III - List of medicines incorporated by CONITEC with the respective $5^{\text {th }}$ level ATC classification and its indications to the National List of Essential Medicines (RENAME). January 2012 - July 2015, Brazil

\begin{tabular}{|c|c|c|}
\hline Incorporated medicines * & ATC Classification ** & $\begin{array}{l}\text { Indications of Incorporate Medicines defined by claimants' } \\
\text { protocols }\end{array}$ \\
\hline Abatacepte & L04AA24 & Moderate to severe rheumatoid arthritis \\
\hline Abatacepte & L04AA24 & Rheumatoid arthritis \\
\hline Abatacepte & L04AA24 & Rheumatoid arthritis \\
\hline Lanreotida acetate & H01CB03 & Acromegaly \\
\hline Adalimumab & L04AB04 & Rheumatoid arthritis \\
\hline Alfa interferon & L03AB11/L03AB10 & $\begin{array}{l}\text { Adjuvant chemotherapy of cutaneous melanoma in clinical } \\
\text { stage III }\end{array}$ \\
\hline Alfataliglicerase & A16AB11 & Gaucher Disease \\
\hline Ambrisentan & $\mathrm{C} 02 \mathrm{KX} 02$ & Pulmonary Arterial Hypertension (PAH) \\
\hline Azathioprine & L04AX01 & Rheumatoid arthritis \\
\hline Azithromycin pill $250 \mathrm{mg}$ & J01FA10 & Whooping cough \\
\hline Beclomethasone & R03BA01 & Chronic obstructive pulmonary disease-COPD \\
\hline Biotin & A11HA05 & Biotinidase deficiency \\
\hline Boceprevir & J05AE12 & Hepatitis C \\
\hline Boceprevir & J05AE12 & Hepatitis $\mathrm{C}$ (Infection with genotype 1 chronic hepatitis $\mathrm{C}$ virus) \\
\hline Bosentan & $\mathrm{C} 02 \mathrm{KX} 01$ & Pulmonary Arterial Hypertension (PAH) \\
\hline Budesonide & R03BA02 & Chronic obstructive pulmonary disease-COPD \\
\hline Certolizumab pegol & L04AB05 & Rheumatoid arthritis \\
\hline Hydrocortisone cypionate $10 \mathrm{mg}$ & D07AC & $\begin{array}{l}\text { Congenital adrenal hyperplasia, newborns diagnosed in the } \\
\text { National Program for Neonatal Screening-PNTN }\end{array}$ \\
\hline Hydrocortisone cypionate $20 \mathrm{mg}$ & D07AC & $\begin{array}{l}\text { Congenital adrenal hyperplasia, newborns diagnosed in the } \\
\text { National Program for Neonatal Screening-PNTN }\end{array}$ \\
\hline Clobetasol & D07AD01 & Topical psoriasis \\
\hline Chloramphenicol suspension & J01BA01 & Spotted Fever \\
\hline Erlotinib hydrochloride & L01XE03 & Advanced non-small cell lung or metastatic cancer \\
\hline Clozapine & N05AH02 & Affective Bipolar Disorder \\
\hline Darunavir $600 \mathrm{mg}$ & J05AE10 & Antiretroviral therapy for HIV patients \\
\hline Doxycycline injectable & J01AA02 & Spotted Fever \\
\hline Etanercept & L04AB01 & Rheumatoid arthritis \\
\hline Fenoterol & $\mathrm{R} 03 \mathrm{CC} 04$ & Chronic obstructive pulmonary disease-COPD \\
\hline Fingolimode & L04AA27 & 3rd line treatment of Multiple Sclerosis \\
\hline Formoterol & $\mathrm{R} 03 \mathrm{AC} 13$ & Chronic obstructive pulmonary disease-COPD \\
\hline Gefitinib & L01XE02 & Lung cancer \\
\hline Golimumab & L04AB06 & Rheumatoid arthritis \\
\hline Hydroxyurea & L01XX05 & Sickle cell disease \\
\hline $\begin{array}{l}\text { Adjuvant hormone therapy to external } \\
\text { beam radiation therapy (LHRH analog } \\
\text { goserelin and cyproterone) }\end{array}$ & L02AE03 & Prostate cancer \\
\hline $\begin{array}{l}\text { Prior hormone therapy to external } \\
\text { beam radiation therapy (LHRH analog } \\
\text { goserelin and cyproterone) }\end{array}$ & L02AE03 & Prostate cancer \\
\hline
\end{tabular}


TABLE III - List of medicines incorporated by CONITEC with the respective $5^{\text {th }}$ level ATC classification and its indications to the National List of Essential Medicines (RENAME). January 2012 - July 2015, Brazil (cont.)

\begin{tabular}{|c|c|c|}
\hline Incorporated medicines * & ATC Classification ** & $\begin{array}{l}\text { Indications of Incorporate Medicines defined by claimants, } \\
\text { protocols }\end{array}$ \\
\hline Infliximab & L04AB02 & Rheumatoid arthritis \\
\hline Lamotrigine & N03AX09 & Affective Bipolar Disorder \\
\hline Maraviroc & J05AX09 & Adult patients previously treated and infected with HIV-1 virus \\
\hline Maraviroc & J05AX09 & $\begin{array}{l}\text { Treatment of adult patients previously treated and infected with } \\
\text { HIV-1 virus }\end{array}$ \\
\hline Imatinib mesylate & L01XE01 & Hypereosinophilic syndrome - SHE \\
\hline Imatinib mesylate & L01XE01 & Adjuvant Chemotherapy, gastrointestinal stromal tumor \\
\hline Methotrexate injection & L01BA01 & Ankylosing spondylitis \\
\hline Methotrexate injection & L04AX03 & Psoriasis \\
\hline Naproxen & M01AE02 & Rheumatoid arthritis \\
\hline Naproxen & M01AE02 & Psoriatic arthritis \\
\hline Naproxen & M02AA12 & Ankylosing spondylitis \\
\hline Olanzapine & N05AH03 & Affective Bipolar Disorder \\
\hline Palivizumab & J06BB16 & Prevention of infection by respiratory syncytial virus \\
\hline Penicillin & $\mathrm{J} 01 \mathrm{C}$ & Prevention of Congenital Syphilis \\
\hline Penicillin oral & $\mathrm{J} 01 \mathrm{C}$ & Sickle cell disease in children \\
\hline Quetiapine & N05AH04 & Affective Bipolar Disorder \\
\hline Raltegravir & J05AX08 & Antiretroviral therapy for HIV patients \\
\hline Risperidone & N05AX08 & Child's autism \\
\hline Risperidone & N05AX08 & Affective Bipolar Disorder \\
\hline Rituximab & $\mathrm{L} 01 \mathrm{XC} 02$ & Follicular lymphoma \\
\hline Rituximab & L01XC02 & Rheumatoid arthritis \\
\hline Rituximab & $\mathrm{L} 01 \mathrm{XC} 02$ & Rheumatoid arthritis \\
\hline Salbutamol & $\mathrm{R} 03 \mathrm{AC} 02$ & Chronic obstructive pulmonary disease-COPD \\
\hline Salmeterol & $\mathrm{R} 03 \mathrm{AC} 12$ & Chronic obstructive pulmonary disease-COPD \\
\hline Sildenafil & G04BE03 & Systemic sclerosis \\
\hline Tacrolimus & L04AD02 & Primary Nephrotic syndrome \\
\hline Thalidomide & L04AX02 & Myelodysplastic syndrome \\
\hline Telaprevir & J05AE11 & $\begin{array}{l}\text { Hepatitis C (genotype } 1 \text { infection Chronically by the hepatitis } \\
\text { C virus) }\end{array}$ \\
\hline Tocilizumab & L04AC07 & Rheumatoid arthritis \\
\hline Tocilizumab & L04AC07 & Rheumatoid arthritis \\
\hline Trastuzumab & L04AC07 & Early breast cancer \\
\hline Trastuzumab & L01XC03 & Advanced breast cancer \\
\hline Trastuzumab & L04AC07 & Early breast cancer \\
\hline Influenza vaccine & J07BB03 & Chronic obstructive pulmonary disease-COPD \\
\hline $\begin{array}{l}\text { Vaccine Adsorbed diphtheria, tetanus } \\
\text { and pertussis }\end{array}$ & J07CA06 & Vaccinating Pregnant Women \\
\hline Vaccine Adsorbed Hepatitis A (inactive) & $\mathrm{J} 07 \mathrm{BC} 02$ & Active immunization \\
\hline HPV vaccine & J07BM02 & Prevention of cervical cancer \\
\hline
\end{tabular}


TABLE III - List of medicines incorporated by CONITEC with the respective $5^{\text {th }}$ level ATC classification and its indications to the National List of Essential Medicines (RENAME). January 2012 - July 2015, Brazil (cont.)

\begin{tabular}{lcl}
\hline Incorporated medicines * & ATC Classification ** & $\begin{array}{l}\text { Indications of Incorporate Medicines defined by claimants } \\
\text { protocols }\end{array}$ \\
\hline $\begin{array}{l}\text { HPV vaccine } \\
\begin{array}{l}\text { Vaccine for measles, rubella, mumps } \\
\text { and chicken pox. }\end{array}\end{array}$ & $\begin{array}{l}\text { Prevention of cervical cancer } \\
\text { Jctive immunization }\end{array}$ \\
$\begin{array}{l}\text { Vacine Tdap-R } \\
\text { HPV vaccine }\end{array}$ & J07AM51 & $\begin{array}{l}\text { Booster vaccination against diphtheria, tetanus and whooping } \\
\text { cough, in individuals over four years. }\end{array}$ \\
$\begin{array}{l}\text { Tetraviral vaccine (measles, mumps, } \\
\text { rubella and chickenpox) }\end{array}$ & J07BD54 & $\begin{array}{l}\text { Prevention of cervical cancer and diseases related to HPV } \\
6,11,16 \text { and } 18\end{array}$ \\
\hline
\end{tabular}

* The same medicine may appear on the table related to the same ATC classification for three reasons: 1) multiple demands for different indications or uses of the same medicine; 2) multiple demands of the same medicine for the same indication, but in different presentations (dosages) and 3 ) repetition of the same demand for the same indication by different claimants. ${ }^{* *}$ ATC $=$ Anatomical Therapeutic Chemical

TABLE IV - Distribution of reasons for non-incorporation of medicines requested. January 2012 - July 2015, Brazil

\section{Reasons for non-incorporation of medicines}

Studies showed limited results of efficacy and/or safety of the medicine in question or do not establish clinical benefit

The limited economic analysis and budget impact analysis are presented with underestimated uncertainties of estimates generated by cost-effective analysis

Available scientific evidence does not prove the superiority of these medicine s from the medicinal product already available on SUS, and the results of economic analysis (sensitivity analysis) showed higher cost and lower effectiveness

\begin{tabular}{|c|c|c|}
\hline $\begin{array}{l}\text { Lack of studies on the effects of long-term use of the medicine and assessment of } \\
\text { associated adverse events. }\end{array}$ & 15 & 12.5 \\
\hline $\begin{array}{l}\text { Low methodological quality of the studies and characteristics of questionable selection } \\
\text { criteria }\end{array}$ & 10 & 8.4 \\
\hline $\begin{array}{l}\text { Average duration of clinical and/or size of the sample for evaluation of medicine efficacy } \\
\text { for the treatment of specific disease are insufficient }\end{array}$ & 9 & 7.5 \\
\hline $\begin{array}{l}\text { Presented studies were not robust enough (lack of evidence) to prove the effect of its } \\
\text { use in the proposed scenario }\end{array}$ & 7 & 5.8 \\
\hline Ideal dose has not been established & 5 & 4.2 \\
\hline Considerable incidence of adverse events & 3 & 2.5 \\
\hline Total & 120 & 100 \\
\hline
\end{tabular}

because this number reflects only those cases in which these bodies provoked CONITEC to perform the inclusion analysis.

This provocation can occur prior to the filing of a lawsuit, in a previous procedure of a civil action instruction, for example; or already in the course of action when the judiciary body understands that it is not entitled to such an incorporation decision, because it presents a highly technical character. In cases, however, that the incorporation of the demand has been previously denied by CONITEC and is forwarded to the Judiciary, through class actions, another option that has been happening is the emission of court orders that lead to the modification of SUS technologies lists, without following technical HTA 
criteria (Guimarães, 2014). Once there is, in such cases, judicial decision with res judicata requiring the inclusion of a medicine, CONITEC, at first, may not go against it for technical reasons. Beyond these actions, judicialization is still a very pulverized phenomenon, with individual actions and lawsuits, seeking the provision of certain technologies for a single individual claimant without the technology being added to the lists of SUS (Grinover et al., 2014).

Among the completed processes, the incorporation decisions correspond numerically to a little less than double the non-incorporation decisions. The high rate of non-incorporation for merit grounds coincides with the fact that Decree No. 7,646/2011 began to demand a more rigorous, technical evaluation, by the emission of a report by the plenary of the CONITEC, in which the following elements will be examined: scientific evidence on the efficiency, accuracy, effectiveness and safety of the medicine, product or procedure at the center of the process; comparative economic evaluation of benefits and costs in relation to already embedded technologies; the impact the inclusion of technology to SUS will have (CONITEC, 2015). On the other hand, this amount of inclusion decisions is also an important finding and proves that the Ministry of Health and the CONITEC are recognizing the need to complement the RENASES and the RENAME, offering new health technologies more efficient than those already available to the population.

The ordinary increase in the number of produced and embedded technologies can be understood in the light of the increase in the volume of knowledge and information produced on medical technologies (Cutler, Macclellan, 2001; Lichtenberg, 2001). These, in turn, favor immediate care, diagnostic accuracy, and provide more security to the whole multidisciplinary team and also bring other benefits to public health in general. In Brazil, the health sector is the largest component of all scientific and technological production, thus generating the necessary incentive for new fundamental technology breakthroughs to improve quality of life for the population and promote the healing of diseases (Brasil, 2008).

Not surprisingly, the bulk of inclusion requests are for medicines, since research and innovation related to this type of technology also dominate the market and the scientific community (Brasil, 2011c). The CONITEC's claimants, therefore, desire to complement RENASES with further actions and health services available to the population, as well as RENAME with further drugs, which becomes evident by the predominance of requests for inclusion of new technologies, in particular the inclusion of antineoplastic/immunomodulatory medications and anti-infective medicines for systemic use.
The reasons for the high frequency of antineoplastic/ immunomodulatory medicines may be related: 1) the high cost of treatment with these medicines, involving cuttingedge and high complexity technologies affecting not only social classes that usually use SUS, but also patients from medium or even higher classes; 2) the determinations of the National Policy of Oncology Care (Vianna et al., 2005) and the goals established by the Ministry of Health's Strategic Plan 2011-2015, which led to the organization of the Ministry of Health and the Health Departments of the States and Cities to promote, coordinate and implement strategic projects of technological resources using costeffectiveness, efficacy and quality studies and technology assessment of cancer care in Brazil (Kligerman, 2000; Brasil, 2005) and, 3) the high levels of judicialization demands, seeking the coverage of these medicines, especially Rituximab and Trastuzumab, with high costs to the public budget (Portal da Justiça Federal, 2015).

The antineoplastic medicines are an exception to RENAME (as are the ophthalmologic and those used in emergency procedures) because they have a different system of supply and their financing comes from High Complexity Procedure Authorizations (APAC). The only antineoplastic medicines that are provided directly by SUS are Thalidomide, Trastuzumab and Imatinib Mesylate. Antineoplastic drugs are not included on a list, but on chemotherapeutic procedures registered on APAC's forms in the System of Outpatient Information of SUS. Only hospitals authorized by the Health Ministry to perform oncology procedures may supply and use these medicines. The payment follows a list of codes registered on APAC's forms. The hospitals are responsible for the acquisition and supply of these types of drugs and are refunded monthly after presenting the codes to the Health's Secretary. It's worth mentioning, however, that the HPV vaccine and Thalidomide are listed on the $9^{\text {th }}$ edition of RENAME, as are Tocilizumabe, Rituximabe, Muromonabe, Natalizumabe, Infliximabe, Golimumabe, Daclizumabe, Certolizumbae Pegol, Basiliximabe and Adalimumabe (Brasil, 2013b).

The inclusion of those medicines, which use had already been constantly granted by the courts, allows the management to acquire them on a large scale and through a bidding process, which reduces the cost to the health budget. The high incorporation of anti-infective medicines, on the other hand, may be related to bacterial resistance. Systemic use of these medicines leads to increasing resistance of microorganisms to products already available at SUS. The high consumption of an antimicrobial species may, therefore, result in the development of bacterial resistance, creating the need for the incorporation to SUS 
of new medicines for the treatment of resistant organisms (Dias, Monteiro, Menezes, 2010).

The results also demonstrate a social clamor for compliance with the principle of integrality of SUS' coverage. The fact is that public health investment in Brazil is still far from ideal. According to the 2012 statistics of the World Health Organization (WHO), Brazil, among the countries with universal public service models, has the lowest state participation in health financing. Of the entirety of the federal budget, only $4.7 \%$ of public expenditure was allocated to health in 2001, a percentage that increased to $8.7 \%$ in 2014 , but is still below the world average (11.7\%) and even the African countries average $(10.6 \%)$. Not only does the country lack priority to health in terms of budget allocation, but also in terms of Gross Domestic Product (GDP) percentage and, especially, a control over expenditures, when, in reality, we see that many resources available for health are spent on other areas by the management (World Health Statistics, 2015).

It is important, therefore, to track how public administrators distribute the limited budget resources of SUS between a growing number of technologies, thus preventing the constant expansion of coverage from leading to scarcity of resources, hampering access. In other words, an increasingly comprehensive coverage will mean little, with an increasing number of technologies theoretically available to the public, if, in reality, these technologies cannot be made available due to lack of resources.

Although numerically not very significant, the requests for expansion of the medicine's use are also reflexes of the progress in medicine research, indicating the discovery of new therapeutic uses for existing medicines on the market. Expanding the usage and indications would extend SUS coverage because it gives health professional a new alternative treatment based on already available and accessible technology in SUS.

The study also shows that many of the requests were rejected due to non-compliance of the forwarded formal documentation, especially from the pharmaceutical industry. This result is attributed to the fact that there were alterations in the CITEC procedure, in which there was no requirement documents for the protocol of procedures in favor of the CONITEC process, which in turn created a minimum list of necessary documentation for the demands to pass from the preliminary examination by the Executive Secretariat to the plenary commission; as well as the standards adaptation period for submitting demands by the industry in this new reality (DECIT, 2011; CONITEC, 2015). The only application in which the demand was unnecessary because the technology had already been included by the RENASES and RENAME before the application came from a civil association. Considering the above, it is essential that these institutions have better assistance and specific information about the new CONITEC procedures, thus ensuring effective participation in these processes, representing organized civil society. Moreover, this measure will avoid wasted CONITEC resources, by assessing unnecessary demands.

Analyzing the volume of rejected decisions for non-conformity of documentation makes it clear that the reforms in the regulation process since 2011 were positive, with the creation of a terminative decision, dissociated from the analysis of request merit, for those cases of formal divergence or lack of documents in the application. The trend over these first three years is that the more the public knows about this relationship and the more experienced and knowledgeable those interested parties are, the fewer cases of rejection will occur by non-compliance of formal documentation, thus making the process more efficient and transparent.

This innovation, along with the establishment of a period for a CONITEC decision (180 days), which did not occur in the previous system, made the process most expeditious and efficient, making it possible to verify a significant increase in the number of decisions issued by CONITEC compared with CITEC. While this one presented decisions for 224 processes between 2006 and 2011 (Silva, Petramale, Elias, 2012), that one has already completed 359 demands from 2012 to July 2015 (CONITEC, 2015).

On the other hand, the non-incorporation of certain medicines due to merit rejection by the CONITEC is a consequence of the more strict criteria required by the new legislation, related to the investigation of the clinical, economic and social consequences of the technologies use as HTA process, which result in the refusal of inclusion requests due to a technical basis, generating a real administrative jurisprudence and CONITEC technique, which allows for transparent and objective knowledge by the interested parties, by the Ministry of Justice and the general public of the technical criteria used by the committee.

Advertising these decisions also depends upon the private press, with the TV news and other media responsible for the wide and swift dissemination of the new technologies included in SUS, which will be available to the public, so that people know their rights to obtain access to these technologies, and can demand respect for the 180 days period, provided for in Article 25 of Decree No. 7,646/2011 (Brasil, 2011b).

Civil society showed a great interest in participating in these public consultations, provided in art. 19 of Decree 
No. 7,646/2011, which made the evaluation process more democratic and pluralistic (Brasil, 2011b).; Delduque, Dallari, Alves, 2014.). Thus, the comparison of documents submitted for public consultation with the fundamentals of CONITEC's decisions may have contributed in assisting final decisions in the processes of inclusion, exclusion or alterations of technologies to SUS.

\section{CONCLUSION}

Since 2011, with the creation of CONITEC and with the important innovations in the Brazilian legislation regarding this process, there was a substantial improvement of the HTA management tools in the country. Changes such as public consultations as a mandatory step, made the process more democratic and the possibility of dismissal of the case by formal inconsistency made the committee analysis of the documentation more prompt.

Three years of requests submitted to CONITEC were analyzed and we found that the public entities were the largest claimants, followed by companies and laboratories, and finally, private non-profit associations, which are responsible for a small number of applications.

Regarding those medicines rejected for inclusion in CONITEC, we found that the main reasons these results were negative was the fact that the medicine studies in question had limited efficacy and/or safety results or failed to establish clinical benefits.

A trend became evident, regarding the inclusion of anticancer/immunomodulatory and anti-infective medicines for systemic use, which has been shown according to surveys and recent publications on the growth of these medicines.

The data collected also led to the conclusion that almost all of the cases to date sought only to add technologies to SUS, generating a budget concern about the possibility of providing these technologies to the population. This reality reinforces the criticism of low public investment to health in the country, due to the lack of priority for this sector, and highlights the health manager's challenge in balancing the increasing demand with the reality of insufficient State resources.

The process of inclusion, exclusion and alteration of technologies to SUS needs to be constantly monitored, with data collection, processing and categorization of the demands submitted to CONITEC, to compare the empirical results of the processes with the expectations and plans of management, as well as the concerns of service users and programmatic nature studies in the HTA area.

\section{CONFLICT OF INTEREST}

The authors report no conflict of interest with the analyzed data and not with the institutions mentioned.

\section{REFERENCES}

BANTA, R.; ALMEIDA, R.T. The development of health technology assessment in Brazil. Int. J. Technol. Assess. Health., v.25, n.1, p.255-9, 2009.

BRASIL. Decreto n ${ }^{\circ}$ 7.646, de 21 de Dezembro de 2011. Dispõe sobre a Comissão Nacional de Incorporação de Tecnologias no Sistema Único de Saúde e sobre o processo administrativo para incorporação, exclusão e alteração de tecnologias em saúde pelo Sistema Único de Saúde - SUS, e dá outras providências. Diário Oficial da República Federativa do Brasil, Poder Executivo, Brasília, DF, 22 dez. 2011. Disponível em: <http://www.planalto.gov.br/ ccivil_03/_Ato2011-2014/2011/Decreto/D7646.htm>. Access: 4 dez. 2015. (a).

BRASIL. Decreto $n^{\circ} 8.065$, de 7 de agosto de 2013. Aprova a Estrutura Regimental e o Quadro Demonstrativo dos Cargos em Comissão e das Funções Gratificadas do Ministério da Saúde e remaneja cargos em comissão. Diário Oficial da República Federativa do Brasil, Poder Executivo, Brasília, DF, 7 ago. 2013. Disponível em: <http://www.planalto.gov. br/ccivil_03/_Ato2011-2014/2013/Decreto/D8065.htm>. Access: 17 jul. 2014. (a)

BRASIL. Lei ${ }^{\circ} 12.401$, de 28 de Abril de 2011. Altera a Lei no 8.080, de 19 de setembro de 1990, para dispor sobre a assistência terapêutica e a incorporação de tecnologia em saúde no âmbito do Sistema Único de Saúde SUS. Diário Oficial da República Federativa do Brasil, Poder Executivo, Brasília, DF, 29 abr. 2011. Disponível em: $<$ http://www. planalto.gov.br/ccivil_03/_Ato2011-2014/2011/Lei/ L12401.htm>. Access: 04 dez. 2015. (b)

BRASIL. Lei no 9.784, de 29 de Janeiro de 1999. Regula o processo administrativo no âmbito da Administração Pública Federal. Diário Oficial da República Federativa do Brasil, Poder Executivo, Brasília, DF, 01 fev. 1999. Disponível em: < http://www.planalto.gov.br/ccivil_03/ leis/L9784.htm>. Acess: 12 jan. 2015.

BRASIL. Ministério da Saúde. Avaliação econômica em saúde: desafios para gestão no SUS. Brasília: Ed. Ministério da Saúde, 2008. (Série A. Normas e Manuais Técnicos). 104p. 
BRASIL. Ministério da Saúde. Manual de bases técnicas em oncologia do Ministério da Saúde. Brasília: Ministério da Saúde, 2013. 116p. Disponível em: <http://bvsms.saude. gov.br/bvs/publicacoes/inca/manual_oncologia_14edicao. pdf $>$. Acesso em: 10 out. 2016. (b)

BRASIL. Ministério da Saúde. Monitoramento do horizonte tecnológico em saúde no âmbito da Rebrats. Brasília: Ed. MS, 2011. (Série B. Textos Básicos em Saúde). p.2-3. (c)

BRASIL. Ministério da Saúde. Política Nacional de Gestão de Tecnologias em Saúde. Brasília: Ministério da Saúde, 2010. (Série B. Textos Básicos em Saúde). 48p.

BRASIL. Ministério da Saúde. Relação nacional de medicamentos essenciais. 5.ed. Brasília: Ministério da Saúde, 2007. 285p.

BRASIL. Portaria ${ }^{\circ} 2.439$, de 8 de dezembro de 2005. Institui a Política Nacional de Atenção Oncológica: promoção, prevenção, diagnóstico, tratamento, reabilitação e cuidados paliativos, a ser implantada em todas as unidades federadas, respeitadas as competências das três esferas de gestão. Diário Oficial da República Federativa do Brasil, Poder Executivo, Brasília, DF, 8 dez. 2005. Disponível em:< http:/bvsms.saude.gov.br/bvs/saudelegis/gm/2005/ prt2439_08_12_2005.html>. Access: 16 nov. 2015.

BRASIL. Portaria n ${ }^{\circ} 2.647$, de 4 de novembro de 2013. Institui a Rede Brasileira de Centros e Serviços de Informação sobre medicamentos (REBRACIM). Diário Oficial da República Federativa do Brasil, Poder Executivo, Brasília, DF, 4 nov. 2014. Disponível em:< http://bvsms.saude.gov.br/bvs/ saudelegis/gm/2013/prt2647_04_11_2013.html>.Access: 11 mar. 2014. (c)

CAPUCHO, H.C.; SALOMON, F.C.R.; VIDAL, A.T.; LOULY, P.G.; SANTOS, V.C.C.; PETRAMALE, C.A. Incorporação de tecnologias em saúde no Brasil: novo modelo para o Sistema Único de Saúde. BIS, v.13, n.3, p.1215-1222, 2012.

COMISSÃO NACIONAL DE INCORPORAÇÃO DE TECNOLOGIAS. CONITEC. Disponível em: $<$ http://portal.saude.gov.br/portal/arquivos/pdf/ oquemudadacitecparaconitec_23022012.pdf>. Access: 01 ago. 2015 .

DELDUQUE, M.C.; DALLARI, S.G.; ALVES, S.M.C. Decreto que institui a Política Nacional de Participação Social: impactos na saúde. Cad. Saúde Pública, v.30, n.9, p.1-3, 2014.
DEPARTAMENTO DE CIÊNCIA E TECNOLOGIA. DECIT. Secretaria de Ciência, Tecnologia e Insumos Estratégicos. Informes Técnicos Institucionais "Nova Comissão Nacional de Incorporação de Tecnologias de Saúde e impacto ao Sistema Único de Saúde”. Rev. Saúde Pública v.45, n.5, p.993-966, 2011.

DIAS, M.; MONTEIRO, M.S.; MENEZES, M.F. Antibióticos e resistência bacteriana, velhas questões, novos desafios. Cad. Otorrinolaringol., 12p., 2010.

EDDY, D. Health technology assessment and evidence-based medicine: what are we talking about? Value Health, v.12, n.2, p.6-7, 2009.

GRINOVER, A.P.; WATANABE, K.; SICA, L.P.P.P.; ALVES, L.S.; SADEK, M.T.; LANGENEGGER, N.; FERREIRA, V. Avaliação da prestação jurisdicional coletiva e individual a partir da judicialização da saúde. São Paulo: Fundação Getúlio Vargas, Centro de Pesquisa Jurídica Aplicada, 2014. (Relatório de Pesquisa). 93p.

GUIMARÃES, R. Incorporação tecnológica no SUS: o problema e seus desafios. Cienc. Saúde. Coletiva., v.19, n.12, p.4899-4908, 2014.

KLIGERMAN, J. Ampliação da assistência oncológica no Brasil. Rev. Bras. Cancerol., v.46, n.4, p.347-9, 2000.

LICHTENBERG, F.R. Are the benefits of newer drugs worth their cost? evidence from the 1996, MEPS. Health Affair, v. 20, n.5, p.241-251, 2001.

NOVAES, H.M.D.; ELIAS, F.T.S. Uso da avaliação de tecnologias em saúde em processos de análise para incorporação de tecnologias no Sistema Único de Saúde no Ministério da Saúde. Cad. Saúde Pública, v.29, n.1, p.7-16, 2013.

PORTAL DA JUSTIÇA FEDERAL. Disponível em: < http:// columbo2.cjf.jus.br/juris/unificada/ $>$. Acesso em: $06 \mathrm{fev}$. 2015.

SILVA, H.P.; PETRAMALE, C.A.; ELIAS, F.T.S. Avanços e desafios da Política Nacional de Gestão de Tecnologias em Saúde. Rev. Saúde Pública, v.46, p.83-90, 2012. 
VIANNA, S.M.; NUNES, A.; GÓES, G.; SILVA, J.R.; SANTOS, R.J.M. Atenção de alta complexidade no SUS: desigualdades no acesso e no financiamento. Brasília: Ministério da Saúde; IPEA, 2005. 160p. Disponível em: $<$ http://getinternet.ipea.gov.br/economiadasaude/adm/ arquivos/destaque/alta_complexidade.pdf $>$. Access: 11 jul. 2015.
WORLD HEALTH STATISTICS. 2015. Disponível em: $<$ http://www.who.int/gho/publications/world_health_ statistics/2015/en/>. Accesso: 13 oct. 2015.

Received for publication on 24 $4^{\text {th }}$ April 2016 Accepted for publication on $25^{\text {th }}$ October 2016 